\title{
Editorial
}

Editorial

\section{Digital transformations and value creation in international markets}

This Special Issue, titled "Digital transformations and value creation in international markets," presents a collection of articles that make a meaningful contribution to academia and encourage outstanding research on digital transformations and the subsequent value creation that takes place on an international level. The reviewers have highlighted the following articles for inclusion in this Special Issue. An overview of these articles is presented below. The main topics covered are entrepreneurship, innovation and international venture capital (VC).

Entrepreneurship and corporate ventures are becoming key elements in the generation of worldwide wealth and value creation through digitalisation and e-businesses (Amit and Zott, 2001). This is so because new ventures are internationalising their activities in their early stages. This international expansion affects firm's technological learning (Zahra et al, 2000). In pursuit of value creation in international markets, elements such as social capital and trust are strongly connected to the level of resource exchange within a company, which has major consequences for innovation (Tsai and Ghoshal, 1998).

The first article, "Entrepreneurial intentions in an international university environment", by Gieure, Benavides-Espinosa and Roig-Dobón, analyses the personal, social and environmental factors that potentially influence students' entrepreneurial intentions. The authors apply the theory of planned behaviour. The main conclusion is that knowledge and training raise students' propensity to start a business. Moreover, entrepreneurial skills play a relevant role in entrepreneurial intentions.

The article, "Entrepreneurial attitudes in the structure of the economic mind of young people: the case of developing an author questionnaire", by Zabelina, Deyneka and Tsiring, examines economic attitudes with respect to entrepreneurship and investment activities. The main conclusions include presenting two separate ways of adapting students to a market economy. Some students have a positive attitude towards entrepreneurship and investment activities. In contrast, there is a negative tendency towards entrepreneurship and investment, which is reflected by a mistrust of financial institutions and an unwillingness to contribute to the economy.

The third article, "The entrepreneurial profile after failure", by Espinoza-Benavides and Díaz, examines the profile of entrepreneurs that have failed in previous businesses but that nevertheless decide to start or continue with another. The results show a difference in the entrepreneurial profile of entrepreneurs who have failed and those who have not failed recently in Chile.

In the next article, "An organisational framework for analysis of crowdsourcing initiatives", Martinez-Corral, Grijalvo and Palacios study the emergence of crowdsourcing as a new trend in problem solving and value creation in digital innovation. They analyse the dimensions that characterise many crowdsourcing models and compare them with the elements for new organisations. The results reveal a link between crowdsourcing models and organisational models. This connection is developed through the relationship between the dimensions and elements of the different models.

The article "Risk, capabilities, and international venture capital syndication in China", by Pezeshkan, Smith, Fainshmidt and Zhang, presents a holistic model of VC firm syndication decisions in China. The authors argue that $\mathrm{VC}$ firms should consider multiple sources of risk (life cycle, operational and political) in relation to their capabilities (knowledge breadth and knowledge depth) when thinking about syndication with local partners. They report that

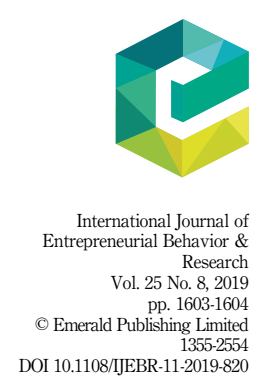


IJEBR

25,8

1604 lower VC firm capabilities are associated with a tendency not to syndicate with a local partner when venture risk factors are low.

In the last article, "Contingency factors and entrepreneurship: the influence on business activity”, Cabrer-Borrás, Rico Belda and Botella Carrubi analyse the factors that are crucial for the survival of companies in Spain. The study has two separate focuses, considering companies with and companies without employees. The results show that size, longevity, productivity, financial leverage, positive profitability and liquidity positively affect the survival of companies. However, profitability and level of debt seem not to influence the survival rate.

These articles shed light on value creation in digital businesses on an international level. This plays a pivotal role in fostering entrepreneurship worldwide, achieving a sustained competitive advantage and promoting technological learning. The results place managerial attitudes and practices at the core of a business's international capabilities. These studies contribute not only to knowledge of entrepreneurial attitudes on an international level but also to knowledge of venture innovation and value creation.

\section{Carla Martínez-Climent, María Rodríguez-García and Domingo Ribeiro-Soriano}

\section{References}

Amit, R. and Zott, C. (2001), "Value creation in e-business", Strategic Management Journal, Vol. 22 Nos 6-7, pp. 493-520.

Tsai, W. and Ghoshal, S. (1998), "Social capital and value creation: the role of intrafirm networks", Academy of Management Journal, Vol. 41 No. 4, pp. 464-476.

Zahra, S.A., Ireland, R.D. and Hitt, M.A. (2000), "International expansion by new venture firms: international diversity, mode of market entry, technological learning, and performance", Academy of Management Journal, Vol. 43 No. 5, pp. 925-950. 